\title{
TU/e EmonONEN

\section{Synergy in lignin upgrading by a combination of Cu-based mixed oxide and Ni-phosphide catalysts in supercritical ethanol}

\section{Citation for published version (APA):}

Koranyi, T. I., Huang, X., Coumans, A. E., \& Hensen, E. J. M. (2017). Synergy in lignin upgrading by a combination of Cu-based mixed oxide and Ni-phosphide catalysts in supercritical ethanol. ACS Sustainable Chemistry \& Engineering, 5(4), 3535-3543. https://doi.org/10.1021/acssuschemeng.7b00239

DOI:

10.1021/acssuschemeng.7b00239

Document status and date:

Published: 01/04/2017

\section{Document Version:}

Publisher's PDF, also known as Version of Record (includes final page, issue and volume numbers)

\section{Please check the document version of this publication:}

- A submitted manuscript is the version of the article upon submission and before peer-review. There can be important differences between the submitted version and the official published version of record. People interested in the research are advised to contact the author for the final version of the publication, or visit the DOI to the publisher's website.

- The final author version and the galley proof are versions of the publication after peer review.

- The final published version features the final layout of the paper including the volume, issue and page numbers.

Link to publication

\footnotetext{
General rights

- You may freely distribute the URL identifying the publication in the public portal. follow below link for the End User Agreement:

www.tue.nl/taverne

\section{Take down policy}

If you believe that this document breaches copyright please contact us at:

openaccess@tue.nl

providing details and we will investigate your claim.
}

Copyright and moral rights for the publications made accessible in the public portal are retained by the authors and/or other copyright owners and it is a condition of accessing publications that users recognise and abide by the legal requirements associated with these rights.

- Users may download and print one copy of any publication from the public portal for the purpose of private study or research.

- You may not further distribute the material or use it for any profit-making activity or commercial gain

If the publication is distributed under the terms of Article $25 \mathrm{fa}$ of the Dutch Copyright Act, indicated by the "Taverne" license above, please 


\title{
Synergy in Lignin Upgrading by a Combination of Cu-Based Mixed Oxide and Ni-Phosphide Catalysts in Supercritical Ethanol
}

\author{
Tamás I. Korányi, ${ }^{\dagger}$ Xiaoming Huang, ${ }^{\dagger}$ Alessandro E. Coumans, and Emiel J. M. Hensen*(i) \\ Schuit Institute of Catalysis, Inorganic Materials Chemistry, Eindhoven University of Technology, Den Dolech 2, 5612 AZ, \\ Eindhoven, The Netherlands
}

\section{Supporting Information}

ABSTRACT: The depolymerization of lignin to bioaromatics usually requires a hydrodeoxygenation (HDO) step to lower the oxygen content. A mixed $\mathrm{Cu}-\mathrm{Mg}-\mathrm{Al}$ oxide $(\mathrm{CuMgAlO})_{x}$ is an effective catalyst for the depolymerization of lignin in supercritical ethanol. We explored the use of Ni-based cocatalysts, i.e. $\mathrm{Ni} / \mathrm{SiO}_{2}, \mathrm{Ni}_{2} \mathrm{P} / \mathrm{SiO}_{2}$, and $\mathrm{Ni} / \mathrm{ASA}$ (ASA = amorphous silica alumina), with the aim of combining lignin depolymerization and HDO in a single reaction step. While the silica-supported catalysts were themselves hardly active in lignin upgrading, $\mathrm{Ni} / \mathrm{ASA}$ displayed comparable lignin monomer yield as $\mathrm{CuMgAlO}_{x}$. A drawback of using an acidic support is extensive dehydration of the ethanol solvent. Instead, combining $\mathrm{CuMgAlO}$ with $\mathrm{Ni} / \mathrm{SiO}_{2}$ and especially $\mathrm{Ni}_{2} \mathrm{P} / \mathrm{SiO} \mathrm{O}_{2}$ proved to be effective in increasing the lignin monomer yield, while at the same time reducing the oxygen content of the products. With $\mathrm{Ni}_{2} \mathrm{P} / \mathrm{SiO}_{2}$, the lignin monomer yield was $53 \mathrm{wt} \%$, leading to nearly complete deoxygenation of the aromatic products.

KEYWORDS: Lignin, Supercritical ethanol, Aromatics, Hydrodeoxygenation, $\mathrm{Ni}_{2} \mathrm{P}$

\section{INTRODUCTION}

Biomass is currently mainly used to generate heat and power, satisfying about $10 \%$ of the global primary energy demand. ${ }^{1}$ The use of lignocellulosic biomass is expected to grow as it constitutes a renewable source of fuels and chemicals. Lignocellulosic biomass, which consists of cellulose, hemicellulose and lignin, is the most abundant, fastest growing and cheapest form of land-based biomass. ${ }^{2}$ Although most attention has been focused on the valorization of the cellulosic and hemicellulosic parts of biomass, creating value from lignin is a necessity to make lignocellulosic (2nd generation) biorefineries profitable. Although lignin is usually burned to recover its heating value, it is likely that not all this energy is needed in a biorefinery setting. Chemical conversion processes can add more value to lignin by depolymerizing the three-dimensional network of monomethoxylated (guaiacyl, G), dimethoxylated (syringyl, S) and nonmethoxylated ( $p$-hydroxyphenyl, $\mathrm{H}$ ) phenylpropanoid units. ${ }^{3,4}$ Lignin is considered as a potential future source of biorenewable aromatics. ${ }^{5}$

Several approaches have been explored to depolymerize lignin, involving pyrolysis, hydrocracking, hydrogenolysis, oxidation, and hydrolysis, leading to monomeric units such as cyclic hydrocarbons and aromatics. ${ }^{3,4,6,7}$ Usually, the yield of aromatic monomers is higher when hydrogen or hydrogendonating solvents such as methanol, ${ }^{8,9}$ ethanol, ${ }^{9,10}$ and isopropanol $^{9,11}$ are employed in the hydrogenolysis of lignin. ${ }^{6}$ Lignin can, for instance, be converted into monomeric cyclohexyl derivatives in supercritical methanol at $300{ }^{\circ} \mathrm{C}$. Using a carbon-supported $\mathrm{Ni}$ catalyst, a range of useful hydrocarbon products was obtained in methanol at $200{ }^{\circ} \mathrm{C}$ in the presence of molecular $\mathrm{H}_{2} \cdot{ }^{9}$ Supercritical ethanol is an effective solvent for the catalytic conversion of Kraft lignin at $280{ }^{\circ} \mathrm{C}$ using a carbon-supported Mo-carbide catalyst. ${ }^{10}$ In this approach, no external hydrogen was needed. Iso-propanol has also been mentioned as a promising solvent and hydrogen transfer agent in the depolymerization of organosolv lignin at $300{ }^{\circ} \mathrm{C}$ using Raney Ni catalysts. ${ }^{11}$

We have earlier reported a method to convert lignin into aromatics, making use of a mixed CuMgAl-oxide catalyst. ${ }^{12}$ This one-step approach comprises thermal cracking of lignin in supercritical ethanol and protection of the resulting fragments by reactions with ethanol; it yields predominantly alkylated aromatics in large amounts (>50 wt \%) with no or little char formation. This approach can be employed to convert different types of lignin including Kraft lignin. Detailed investigations have demonstrated that the use of ethanol serves three purposes: it acts as a capping agent to protect intermediate phenolic fragments from repolymerizing (through $\mathrm{C}$ - and $\mathrm{O}$ alkylation), it scavenges formaldehyde obtained by demethoxylation of lignin's methoxy groups, and it provides hydrogen for metal-catalyzed hydrogenolysis reactions. ${ }^{13}$ Recently, we optimized the preparation of the mixed $\mathrm{CuMgAl}$ oxide catalyst and the reaction conditions toward high aromatics yield in the depolymerization of a soda lignin derived from wheat straw. ${ }^{14}$

Usually, hydrodeoxygenation (HDO) is considered as a valuable step to upgrade the phenolic compounds in oils

\footnotetext{
Received: January 22, 2017

Revised: February 28, 2017

Published: March 1, 2017
} 
derived from lignin depolymerization, i.e., to lower the oxygen content. ${ }^{15}$ Alumina-supported CoMo and NiMo sulfides, which are widely used as catalysts for hydrotreating operations in oil refineries, can be used for this purpose. ${ }^{16,17}$ Although these catalysts display high HDO activity in their sulfide form, the sulfur content of lignin-derived bio-oils is too low to maintain the catalyst in the active sulfided state during HDO reactions. ${ }^{18}$ Accordingly, transition metal phosphides have been considered as catalysts to catalyze HDO reactions. ${ }^{18,19}$ The preparation of metal phosphides is relatively straightforward and, similar to conventional hydrotreating catalysts, base metals such as $\mathrm{Ni}$ and Mo make excellent metal phosphide HDO catalysts. ${ }^{18}$ Transition metal phosphides are usually prepared by reduction of a metal salt or oxide precursor in the presence of a phosphorus compound. ${ }^{19}$ In the classical phosphate reduction approach, the support is impregnated with a metal nitrate and ammonium phosphate followed by reduction at high temperatures in the $500-800{ }^{\circ} \mathrm{C}$ range. ${ }^{20}$ As support, silica is preferred over alumina (c.q., aluminum phosphates form, hindering phosphidation of the metal component). ${ }^{21}$ The use of more reactive phosphorus compounds such as phosphite, hypophosphite, and phosphine has also been explored. ${ }^{19,22}$ The benefit of these precursors is that the reduction can be carried out at lower temperatures, which leads to higher dispersion of the final active metal phosphide phase. ${ }^{19}$

Some of us were the first to report that $\mathrm{Ni}_{2} \mathrm{P}$ is an active catalyst for hydrodenitrogenation reactions of oil feedstock. ${ }^{23}$ This catalyst also displays high catalytic activity in hydrodesulfurization reactions. ${ }^{24}$ More recently, the promise of $\mathrm{Ni}_{2} \mathrm{P} /$ $\mathrm{SiO}_{2}$ for the HDO of guaiacol, ${ }^{25-27}$ dibenzofuran, ${ }^{28}$ and methyl-tetrahydrofuran ${ }^{29}$ has been demonstrated. In another study, a bio-oil obtained by pyrolysis of lignocellulosic biomass was upgraded using $\mathrm{Ni}_{2} \mathrm{P} / \mathrm{SiO}_{2}$ as a $\mathrm{HDO}$ catalyst. ${ }^{26}$ Usually, it is found that the HDO activity of nickel phosphides is higher than that of metallic Ni catalysts. ${ }^{30}$ In this context, it is interesting to mention that metallic $\mathrm{Ni}$ catalysts have been employed for the depolymerization of lignin in the presence of molecular hydrogen yielding substituted alicyclic and aromatic hydrocarbons. $^{31,32}$ A Ni catalyst supported on Al-SBA-15 catalyst was able to convert lignin to cycloalkanes. ${ }^{33}$ Despite the promise of this approach, the high rate of aromatic ring hydrogenation is problematic in view of the process economics. ${ }^{34}$ Ni-based heterogeneous catalysts for energy and environmental applications have been recently reviewed. ${ }^{35}$

In the present study, we report for the first time about the substantial synergy between the earlier described mixed CuMgAl-oxide catalyst and nickel (phosphide) catalysts in the depolymerization of lignin in supercritical ethanol. Under optimized conditions, using $\mathrm{Ni}_{2} \mathrm{P} / \mathrm{SiO}_{2}$ as the $\mathrm{HDO}$ catalyst, a temperature of $340{ }^{\circ} \mathrm{C}$ and a reaction time of $4 \mathrm{~h}$ the monomers yield from soda lignin was $53 \mathrm{wt} \%$. This result compares favorably to the monomer yields obtained in experiments with either of the two catalysts. Also $\mathrm{Ni} / \mathrm{SiO}_{2}$ and $\mathrm{Ni} / \mathrm{ASA}$ (ASA = amorphous silica alumina) catalysts were found to perform in a favorable manner with the mixed $\mathrm{CuMgAlO}_{x}$ catalyst. A detailed comparison was made of lignin conversion under optimized conditions using these catalysts. Our aim was to clarify the influence of the different active phases and supports on the monomer yield and degree of deoxygenation.

\section{EXPERIMENTAL SECTION}

Materials. Protobind 1000 alkali lignin was purchased from GreenValue. It was produced by soda pulping of wheat straw (sulfur-free lignin with less than 4 wt \% carbohydrates and less than 2 wt \% ash). Detailed experimental information (chemicals, detailed catalyst preparation and characterization, lignin residue analysis) is given in the Supporting Information (SI) and in our preceding publications. $^{12-14}$

Catalyst Preparation. Mixed CuMgAl-oxides were prepared by calcination of a hydrotalcite precursor. The $\mathrm{Cu}$ loading was $20 \mathrm{wt} \%$ and the $(\mathrm{Cu}+\mathrm{Mg}) / \mathrm{Al}$ ratio 4 . This catalyst is denoted as $\mathrm{CuMgAlO}_{x}$ or in short as "Cu". Supported Ni catalysts were prepared by pore volume impregnation using an aqueous $\mathrm{Ni}\left(\mathrm{NO}_{3}\right)_{2} \cdot 6 \mathrm{H}_{2} \mathrm{O}$ solution. In all cases, the Ni loading was 10 wt \% (Table 1). As supports, silica

Table 1. Textural Properties of All and Compositions of the Ni Catalysts

\begin{tabular}{ccccccc} 
& $\begin{array}{c}\mathrm{S}_{\mathrm{BET}}{ }^{a} \\
\text { catalyst }\end{array}$ & $\begin{array}{c}\text { pore } \\
\text { volume }\end{array}$ & $\begin{array}{c}\text { average } \\
\text { pore size }\end{array}$ & $\mathrm{Ni}$ & $\mathrm{P}$ & $\mathrm{P} / \mathrm{Ni}$ \\
$\mathrm{m} / \mathrm{g})$ & $\left(\mathrm{cm}^{3} / \mathrm{g}\right)$ & $(\mathrm{nm})$ & $($ wt $\%)$ & $($ wt $\%)$ & $\begin{array}{c}\text { molar } \\
\text { ratio }\end{array}$ \\
$\mathrm{CuMgAlO}_{x}$ & 188 & 0.35 & 7.9 & & & \\
$\mathrm{Ni}_{2} \mathrm{P} / \mathrm{SiO}_{2}$ & 140 & 0.88 & 22.6 & 9.93 & 3.92 & 0.75 \\
$\mathrm{Ni} / \mathrm{SiO}_{2}$ & 181 & 1.15 & 20.6 & 9.65 & & \\
$\mathrm{Ni} / \mathrm{ASA}$ & 322 & 0.57 & 5.3 & 9.94 & & \\
${ }^{a} \mathrm{BET}$ surface area. & & & & & \\
\hline
\end{tabular}

$\left(\mathrm{SiO}_{2}\right.$, pore volume $1.3 \mathrm{~mL} / \mathrm{g}$, surface area $\left.210 \mathrm{~m}^{2} / \mathrm{g}\right)$, and amorphous silica alumina (ASA, pore volume $0.7 \mathrm{~mL} / \mathrm{g}$, surface area $350 \mathrm{~m}^{2} / \mathrm{g}, 55$ wt $\%$ nominal $\mathrm{Al}_{2} \mathrm{O}_{3}$ content) were used. After impregnation, the catalyst precursors were dried and calcined in air. The catalysts are denoted as $\mathrm{NiO} / \mathrm{SiO}_{2}$ and $\mathrm{NiO} /$ ASA. Part of the $\mathrm{NiO} / \mathrm{SiO}_{2}$ catalyst was impregnated with an aqueous solution of $\left(\mathrm{NH}_{4}\right)_{2} \mathrm{HPO}_{4}(\mathrm{P} / \mathrm{Ni}=1$ initial precursor ratio). This phosphate-impregnated catalyst, denoted as $\mathrm{NiO}-\mathrm{P} / \mathrm{SiO}_{2}$, as well as $\mathrm{NiO} / \mathrm{SiO}_{2}$ and $\mathrm{NiO} / \mathrm{ASA}$ were reduced in $\mathrm{H}_{2}$ flow at $620{ }^{\circ} \mathrm{C}$ for $3 \mathrm{~h}$. The resulting reduced catalysts are named $\mathrm{Ni}_{2} \mathrm{P} / \mathrm{SiO}_{2}, \mathrm{Ni} / \mathrm{SiO}_{2}$, and $\mathrm{Ni} / \mathrm{ASA}$. A more detailed description of the preparation of these materials can be found in the SI.

Catalytic Activity Measurements. Soda lignin was converted in a $100 \mathrm{~mL}$ stainless-steel high-pressure Parr autoclave. Typically, the autoclave was charged with a suspension of $0.5 \mathrm{~g}$ catalyst and $1.0 \mathrm{~g}$ lignin in $40 \mathrm{~mL}$ ethanol. When two catalysts were combined, the autoclave was charged with $0.5 \mathrm{~g} \mathrm{CuMgAlO}_{x}$ and $0.5 \mathrm{~g} \mathrm{Ni}$-containing catalysts. When the ratio of $\mathrm{CuMgAlO}$ and $\mathrm{Ni}_{2} \mathrm{P} / \mathrm{SiO}_{2}$ catalysts was optimized, their mass was varied at $0.25,0.5$, and $0.75 \mathrm{~g}$, but the sum of catalyst masses remained $1 \mathrm{~g}$. The reactor was then sealed and purged with nitrogen several times to remove air. After leak testing, the pressure was increased to 10 bar with nitrogen or 30 bar with hydrogen and the reaction mixture was heated to $340{ }^{\circ} \mathrm{C}$ under continuous stirring at $500 \mathrm{rpm}$ within $1 \mathrm{~h}$. After a reaction time of $4 \mathrm{~h}$ (or in one case $8 \mathrm{~h}$ ), the heating oven was removed, and the reactor was allowed to cool to room temperature. A workup procedure was developed to distinguish light (THF-soluble) lignin residue (THF = tetrahydrofuran), heavy (THF-insoluble) lignin residue and char. A detailed description of this workup procedure can be found in our previous report, ${ }^{13}$ and a shortened version is presented in the SI.

The liquid phase product mixture was analyzed by a Shimadzu 2010 GC-MS system equipped with a RTX-1701 column $(60 \mathrm{~m} \times 0.25 \mathrm{~mm}$ $\times 0.25 \mu \mathrm{m}$ ) and a flame ionization detector (FID) together with a mass spectrometer (MS) detector. Identification of products was based on a search of the MS spectra with the NIST11 and NIST11s MS libraries. The GC peaks with the same molecular weight $(\mathrm{Mw})$ were unified and presented by the structure determined by GC-MS. These products were further divided into four groups, namely hydrogenated cyclics ( $-\mathrm{O}$ (oxygen-free) $)\left[\mathrm{HC}^{-\mathrm{O}}\right]$, hydrogenated cyclics $(+\mathrm{O}$ (oxygen-containing $))\left[\mathrm{HC}^{+\mathrm{O}}\right]$, aromatics $(-\mathrm{O})\left[\mathrm{Ar}^{-\mathrm{O}}\right]$, and aromatics $(+\mathrm{O})\left[\mathrm{Ar}^{+\mathrm{O}}\right]$, according to the nature of the ring structure and 
functional groups. The FID response factors were calculated using the Effective Carbon Number (ECN) method ${ }^{36}$ to determine the relative response factors corrected by the molecular weight of the compounds relative to $n$-dodecane, which served as the internal standard. The lignin monomers and ethanol product yields, the aromatic hydrogenation (HYD) and hydrodeoxygenation (HDO) degrees, and the yields of lignin residue (LR) and char were determined as follows:

$$
\begin{aligned}
& \text { yield(lignin monomers, wt } \%) \\
& =\text { weight of monomers/weight of starting lignin } \times 100 \\
& \text { yield(solvent-derived products, wt } \%) \\
& =\text { weight of solvent-derived products/weight of starting ethanol } \\
& \quad \times 100 \\
& \text { yield of lignin residue (wt\%) } \\
& =\text { weight of LR/weight of starting lignin } \times 100 \\
& \text { yield of char }(w t \%)=(\text { weight of char and undissolved catalyst) } \\
& \quad \text { (weight loss in TGA) } \\
& \quad \text { /weight of starting lignin } \times 100
\end{aligned}
$$

aromatic HYD degree (wt\%)

$$
=(\mathrm{HC}(-\mathrm{O})+\mathrm{HC}(+\mathrm{O})) / \text { lignin monomer yield } \times 100
$$

$$
\text { HDO degree }(w t \%)=(\mathrm{HC}(-\mathrm{O})+\operatorname{Aro}(-\mathrm{O}))
$$

$$
\text { /lignin monomer yield } \times 100
$$

The composition of the gas phase was analyzed by sampling a small amount of gas from the autoclave on an Interscience Compact GC system, equipped with Molsieve $5 \AA$ and Porabond $\mathrm{Q}$ columns, each fitted with a thermal conductivity detector (TCD) and an $\mathrm{Al}_{2} \mathrm{O}_{3} / \mathrm{KCl}$ column fitted with a flame ionization detector (FID).

Gel Permeation Chromatography (GPC). GPC analyses were performed on a Shimadzu apparatus equipped with two columns connected in series (Mixed-C and Mixed-D, polymer Laboratories) and a UV-vis detector at $254 \mathrm{~nm}$. The column was calibrated with polystyrene standards. Analyses were carried out at $25{ }^{\circ} \mathrm{C}$ using THF as eluent with a flow rate of $1 \mathrm{~mL} / \mathrm{min}$. For the lignin residue analysis, the sample was prepared at a concentration of $2 \mathrm{mg} / \mathrm{mL}$ in THF. All the samples were filtered using $0.45 \mu \mathrm{m}$ filter membrane prior to injection.

\section{RESULTS AND DISCUSSION}

Figure 1 shows the XRD patterns of the reduced Ni catalysts. Reduction of $\mathrm{NiO}-\mathrm{P} / \mathrm{SiO}_{2}$ leads to phase-pure $\mathrm{Ni}_{2} \mathrm{P} / \mathrm{SiO}_{2}$, while metallic $\mathrm{Ni}$ catalysts were obtained by reducing $\mathrm{NiO}$ / $\mathrm{SiO}_{2}$ and $\mathrm{NiO} / \mathrm{ASA}$. The nominal Ni loading of these catalysts is around $10 \mathrm{wt} \%$. The textural properties of the Ni-based and the $\mathrm{CuMgAlO}$ catalyst are collected in Table 1 . These catalysts were used in different combinations to convert soda lignin in ethanol under supercritical conditions. The reaction temperature was $340{ }^{\circ} \mathrm{C}$, and the reaction time was $4 \mathrm{~h}$. Hydrogen was not added to those reaction experiments that involved the use of $\mathrm{CuMgAlO}_{x}$, as this catalyst produced in situ hydrogen by reforming of ethanol. ${ }^{13,37}$ When only supported Ni was used as the catalyst, the autoclave was pressurized by 30 bar $\mathrm{H}_{2}$ atmosphere. Another experiment involved the use of $\mathrm{Ni}_{2} \mathrm{P}$ / $\mathrm{SiO}_{2}$ in 10 bar $\mathrm{N}_{2}$ atmosphere. The results of these eight reaction experiments are shown in Table 2.

The monomer yields obtained upon reaction of soda lignin using only $\mathrm{Ni}_{2} \mathrm{P} / \mathrm{SiO}_{2}$ and $\mathrm{Ni} / \mathrm{SiO}_{2}$ catalysts were around $10 \mathrm{wt}$

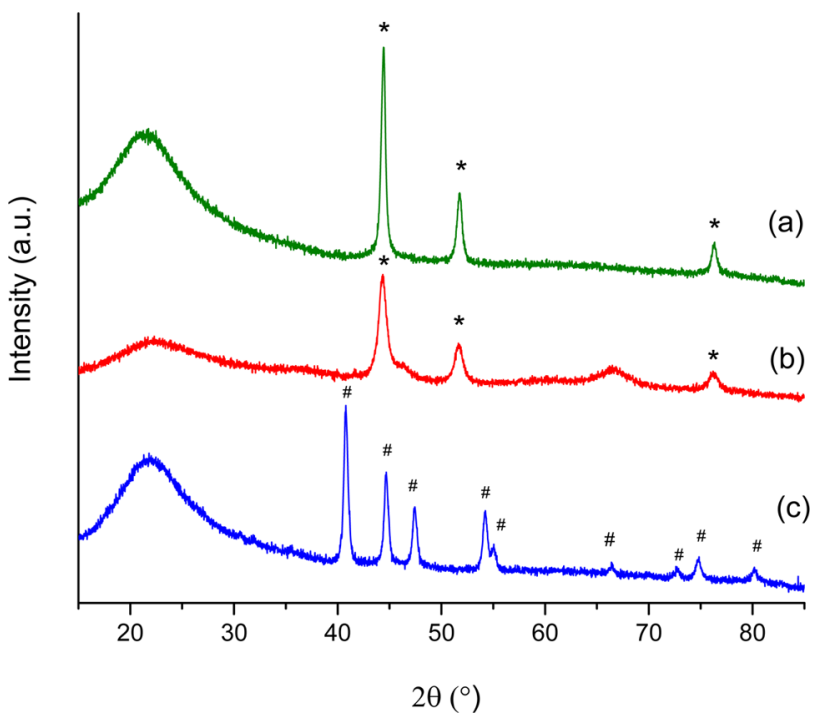

Figure 1. XRD patterns of (a) $\mathrm{Ni} / \mathrm{SiO}_{2}$, (b) Ni/ASA, and (c) $\mathrm{Ni}_{2} \mathrm{P} /$ $\mathrm{SiO}_{2}$ catalysts (* metallic $\mathrm{Ni}$; $\mathrm{Ni}_{2} \mathrm{P}$ ).

$\%$ (entries 2, 3, and 7 in Table 2). These reactions were started in $30 \mathrm{bar}_{2}$ gas (except entry 2 in Table 2), which is equivalent with $75 \mathrm{mmol}$ of hydrogen. Very little $\left(9 \mathrm{mmol}\right.$ for $\mathrm{Ni}_{2} \mathrm{P} / \mathrm{SiO}_{2}$ in $\mathrm{N}_{2}$ ) or a nearly similar amount of hydrogen $(60-70 \mathrm{mmol}$ for $\mathrm{Ni}_{2} \mathrm{P} / \mathrm{SiO}_{2}$ in $\mathrm{H}_{2}$ and $\mathrm{Ni} / \mathrm{SiO}_{2}$ in $\mathrm{H}_{2}$ ) remained after reaction over these catalysts (entries 2,3 , and 7 in Table $\mathrm{S} 1$ ), which implies that hydrogen was not produced $\left(\mathrm{Ni}_{2} \mathrm{P} / \mathrm{SiO}_{2}\right)$ or was not consumed. From this, it can be concluded that lignin depolymerization toward aromatic monomers was very limited when only silica-supported $\mathrm{Ni}$ and $\mathrm{Ni}$-phosphides were used as catalysts.

The use of $\mathrm{CuMgAlO}_{x}$ and $\mathrm{Ni} / \mathrm{ASA}$ catalysts gave similar lignin monomer yields $(27-28 \mathrm{wt} \%$, entries 1 and 5 in Table $2)$. The product distributions of these two reaction experiments were however very different (Figures $2 \mathrm{a}$ and $\mathrm{S} 1$ ): the mixed oxide catalyst yields nearly the same amounts of oxygen-free and oxygen-containing aromatics, whereas the product mixture derived from using $\mathrm{Ni}$ /ASA contains predominantly oxygencontaining aromatics. This difference indicates that the $\mathrm{Ni}$ catalyst is much less active in the HDO of primary oxygencontaining aromatics reaction products. Lercher et al. reported that 18 wt \% lignin monomers (mainly alkanes and naphthalenes, $74 \%$ selectivity) were obtained by depolymerizing lignin over a $30 \mathrm{wt} \% \mathrm{Ni} / \mathrm{ASA}$ catalyst in dodecane at 250 ${ }^{\circ} \mathrm{C}$ in 40 bar hydrogen. ${ }^{31,32}$ In the present study higher lignin monomer yield and lower aromatic ring hydrogenation were obtained at higher reaction temperature $(28 \%$ and $16 \%$, respectively, at $340{ }^{\circ} \mathrm{C}$, entry 5 in Table 2 ). The reason for this can be that these authors used dodecane, while we use ethanol as the solvent. It is known that the solvent has significant influence on product selectivity for hydrogenolysis/ hydrogenation processes. $^{11}$ There is strong evidence that alcoholic solvents such as methanol and ethanol tend to strongly adsorb on the $\mathrm{Ni}$ metal catalyst surface by forming alkoxy species. These alkoxy species partially block the active sites for hydrogenation reactions which explains the much lower rate of aromatic ring hydrogenation activity compared to the reactions in nonpolar alkane solvents. ${ }^{11}$ Besides, extensive alkylation of the aromatic rings by ethanol might also prevent their hydrogenation. 
Table 2. Lignin Monomers Yield Distributions, Aromatic HYD and HDO Degrees, Ethanol Product Yields Obtained after Reaction of Soda Lignin at $340{ }^{\circ} \mathrm{C}$ for $4 \mathrm{~h}$ over Different Catalyst Systems ${ }^{a}$

\begin{tabular}{|c|c|c|c|c|c|c|c|c|c|}
\hline \multirow[b]{2}{*}{ entry } & \multirow[b]{2}{*}{ catalyst } & \multicolumn{5}{|c|}{ lignin monomer yield (wt \%) } & \multirow[b]{2}{*}{ aromatic HYD degree (wt \%) } & \multirow[b]{2}{*}{ HDO degree (wt \%) } & \multirow[b]{2}{*}{ ethanol product yield (wt \%) } \\
\hline & & $\mathrm{HC}^{-\mathrm{O}}$ & $\mathrm{Ar}^{-\mathrm{O}}$ & $\mathrm{HC}^{+\mathrm{O}}$ & $\mathrm{Ar}^{+\mathrm{O}}$ & SUM & & & \\
\hline 1 & $\mathrm{CuMgAlO}_{x}$ & 2.8 & 9.9 & 5.1 & 9.3 & 27 & 29 & 47 & 11 \\
\hline 2 & $\mathrm{Ni}_{2} \mathrm{P} / \mathrm{SiO}_{2}$ & 0.6 & 0.2 & 0.2 & 6.9 & 8 & 9 & 10 & 3 \\
\hline 3 & $\mathrm{Ni}_{2} \mathrm{P} / \mathrm{SiO}_{2}{ }^{b}$ & 0.2 & 0.2 & 0.0 & 9.6 & 10 & 2 & 4 & 5 \\
\hline 4 & $\mathrm{Cu}+\mathrm{Ni}_{2} \mathrm{P} / \mathrm{SiO}_{2}$ & 20.5 & 23.1 & 2.1 & 6.8 & 53 & 43 & 83 & 14 \\
\hline 5 & $\mathrm{Ni} / \mathrm{ASA}^{b}$ & 3.0 & 7.9 & 1.5 & 15.4 & 28 & 16 & 39 & 15 \\
\hline 6 & $\mathrm{Cu}+\mathrm{Ni} / \mathrm{ASA}$ & 14.4 & 22.4 & 2.9 & 9.1 & 49 & 35 & 75 & 26 \\
\hline 7 & $\mathrm{Ni} / \mathrm{SiO}_{2}{ }^{b}$ & 0.2 & 0.8 & 0.2 & 10.3 & 11 & 3 & 8 & 2 \\
\hline 8 & $\mathrm{Cu}+\mathrm{Ni} / \mathrm{SiO}_{2}$ & 20.1 & 21.8 & 4.6 & 5.9 & 52 & 47 & 80 & 14 \\
\hline
\end{tabular}
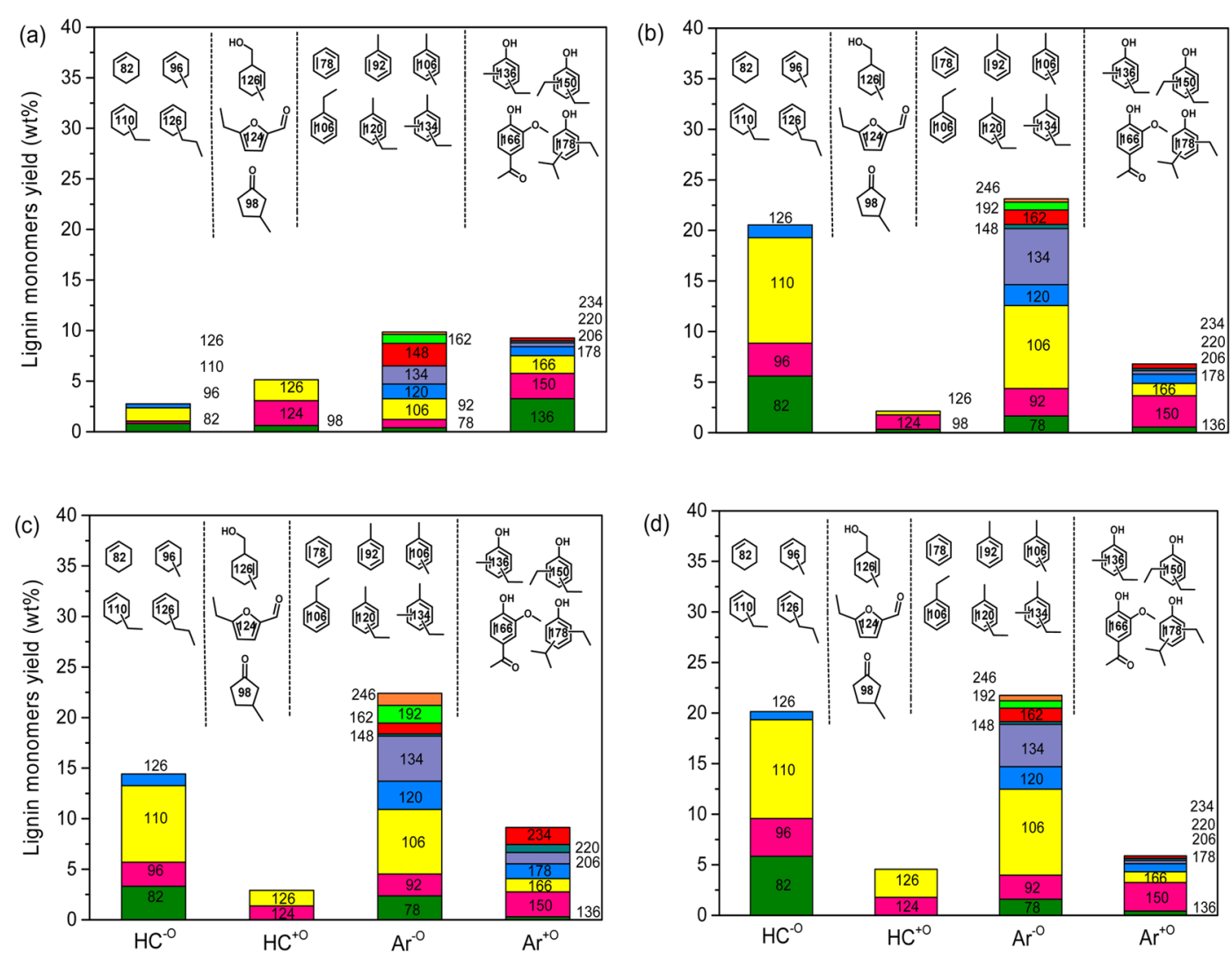

Figure 2. Lignin monomers yield distributions with (a) $\mathrm{CuMgAlO}_{x}$ and combined (b) $\mathrm{CuMgAlO}_{x}+\mathrm{Ni}_{2} \mathrm{P} / \mathrm{SiO}{ }_{2},(\mathrm{c}) \mathrm{CuMgAlO}{ }_{x}+\mathrm{Ni} / \mathrm{ASA}$, and (d) $\mathrm{CuMgAlO}_{x}+\mathrm{Ni} / \mathrm{SiO}_{2}$ catalysts.

In order to improve the monomer yield and HDO degree obtained using $\mathrm{CuMgAlO}_{x}$, we employed combinations of this catalyst with different Ni-based catalysts. Lignin monomer yields using these combined catalyst systems were quite similar, but much higher than with either the $\mathrm{CuMgAlO}_{x}$ or Ni-based catalysts (entries 4, 6, and 8 in Table 2). The product distributions for the combined-catalyst experiments are summarized in Table 2 and presented in more detail in Figure 2. While oxygenated and oxygen-free aromatics were the predominant products in nearly similar amount with $\mathrm{CuMgAlO}_{x}$ as the catalyst, using an additional Ni-based HDO catalyst resulted in a shift of the product mixture toward oxygen-free aromatics and cyclohexenes. Table 2 shows that the total lignin monomer yield is higher for the combined catalyst systems than for the separate experiments, except for the combination of $\mathrm{CuMgAlO}_{x}$ and Ni/ASA. The HDO degree is strongly increased by the combined-catalyst experiments from about 50 to $75 \mathrm{wt} \%$ and higher. The aromatics hydrogenation degree is also increased but to a lesser extent, i.e., from about 30 wt $\%$ of the lignin-derived monomers were hydrogenated when $\mathrm{CuMgAlO}_{x}$ was the only catalyst to $35-47$ wt \% when an additional HDO catalyst was present. The slightly lower aromatics hydrogenation degree in the experiment with $\mathrm{Ni}$ / ASA is consistent with the lower amount of $\mathrm{H}_{2}$ formed as compared with $\mathrm{Ni}_{2} \mathrm{P} / \mathrm{SiO}_{2}$ and $\mathrm{Ni} / \mathrm{SiO}_{2}$ (entries 6, 4, and 8 in Table S1).

The present results are very promising in comparison to HDO of phenolic compounds, for instance obtained by pyrolysis of biomass, which usually results in extensive hydrogenation of the aromatic rings. Typically, noble metals or $\mathrm{Ni}$ are used as catalysts to lower the oxygen content of the phenolic compounds as reviewed by Daud and co-workers. ${ }^{15}$ In 
Table 3. Lignin Monomer Yield, Yields of Lignin Residues and Char and Analysis of the THF-Soluble Lignin Residue after Reaction in Ethanol at $340{ }^{\circ} \mathrm{C}$ for $4 \mathrm{~h}$ over Different Catalyst Systems ${ }^{a}$

\begin{tabular}{|c|c|c|c|c|c|c|c|c|}
\hline \multirow[b]{2}{*}{ entry } & \multirow[b]{2}{*}{ catalyst } & \multirow[b]{2}{*}{ monomers yield (wt \%) } & \multicolumn{3}{|c|}{ THF-soluble lignin residue (LR) } & \multirow[b]{2}{*}{ THF-insoluble LR (wt \%) } & \multirow[b]{2}{*}{ char (wt \%) } & \multirow[b]{2}{*}{ total yield } \\
\hline & & & (wt \%) & $M_{\mathrm{w}}(\mathrm{g} / \mathrm{mol})$ & $\mathrm{O}(\mathrm{wt} \%)$ & & & \\
\hline 1 & $\mathrm{CuMgAlO}_{x}$ & 27 & 65 & 1027 & 14 & 22 & 0 & 114 \\
\hline 2 & $\mathrm{Ni}_{2} \mathrm{P} / \mathrm{SiO}_{2}$ & 8 & 19 & 661 & 17 & 18 & 37 & 82 \\
\hline 3 & $\mathrm{Ni}_{2} \mathrm{P} / \mathrm{SiO}_{2}{ }^{b}$ & 10 & 71 & 865 & 20 & 5 & 1 & 87 \\
\hline 4 & $\mathrm{Cu}+\mathrm{Ni}_{2} \mathrm{P} / \mathrm{SiO}_{2}$ & 53 & 71 & 649 & 11 & 12 & 11 & 147 \\
\hline 5 & $\mathrm{Ni} / \mathrm{ASA}^{b}$ & 28 & 51 & 730 & 12 & 8 & 8 & 95 \\
\hline 6 & $\mathrm{Cu}+\mathrm{Ni} / \mathrm{ASA}$ & 49 & 70 & 711 & 11 & 27 & 14 & 160 \\
\hline 7 & $\mathrm{Ni} / \mathrm{SiO}_{2}{ }^{b}$ & 11 & 51 & 947 & 18 & 8 & 2 & 72 \\
\hline 8 & $\mathrm{Cu}+\mathrm{Ni} / \mathrm{SiO}_{2}$ & 52 & 80 & 984 & 15 & 12 & 12 & 156 \\
\hline
\end{tabular}

comparison with these studies, the aromatics hydrogenation degree in the present study is much lower at very high HDO selectivity. Another aspect worth discussing is the formation of reaction products from ethanol. $\mathrm{Cu}$ and basic sites also catalyze Guerbet $^{38,39}$ and esterification reactions, producing higher alcohols and esters from ethanol (entry 1 in Table S2). ${ }^{14}$ Adding $\mathrm{Ni}_{2} \mathrm{P} / \mathrm{SiO}_{2}$ or $\mathrm{Ni} / \mathrm{SiO}_{2}$ to the $\mathrm{CuMgAlO}$ only slightly increased the conversion of the solvent. This is beneficial, as the unconverted ethanol can be recycled. On the other hand, the use of $\mathrm{Ni} / \mathrm{ASA}$ resulted in much higher ethanol conversion, mainly due to formation of diethyl ether (see Tables S2 and S3). Dehydration of ethanol is catalyzed by acid sites present on alumina and amorphous silica alumina. ${ }^{40}$ Besides diethyl ether, also hydrocarbons are produced using Ni/ASA, which is likely due to a combination of acid-catalyzed dehydration and hydrogenation. This reaction consumes hydrogen and explains the lower aromatic hydrogenation degree. These reactions will not take place on the nonacidic silica-supported Ni catalysts. ${ }^{41}$ While there is clear synergy between the two catalysts with respect to lignin depolymerization, especially with $\mathrm{Ni}_{2} \mathrm{P} / \mathrm{SiO}_{2}$ and $\mathrm{Ni} / \mathrm{SiO}_{2}$, the effect of combining two catalysts appears to be additive with respect to ethanol yield.

We next discuss the lignin residue and char as the byproducts obtained during lignin conversion. The results in terms of lignin monomers yields, THF-soluble and THF-insoluble lignin residues (LR), and char are presented in Table 3. The high yields of THF-soluble lignin residue and the higher than $100 \%$ total yields are due to the significant alkylation of lignin-derived products using the $\mathrm{CuMgAlO}_{x}$ catalyst. ${ }^{14}$ The THF-soluble lignin residue represents fragments of lignin that have been depolymerized to lower molecular weight. ${ }^{12}$ Guerbet and esterification reactions catalyzed by $\mathrm{CuMgAlO}_{x}$ have been found to be more important in suppressing repolymerization of lignin fragments than alkylation reactions by ethanol. ${ }^{14}$ GPC analysis reveals the molecular weight distribution of these fragments in THF-soluble LR (Figures 3 and S2). Accordingly the weight-averaged molecular weight $(\mathrm{Mw})$ of fragments from the single $\mathrm{CuMgAlO}_{x}$ catalyst experiment is the highest (1027 $\mathrm{g} / \mathrm{mol})$. The molecular weights of experiments carried out in the presence of $\mathrm{Ni} / \mathrm{ASA}(711 \mathrm{~g} / \mathrm{mol})$ and $\mathrm{Ni}_{2} \mathrm{P} / \mathrm{SiO}_{2}(649 \mathrm{~g} /$ mol) were significantly lower (Figure 3 and Table 3 ). The elemental composition ( $\mathrm{C}, \mathrm{H}$, and $\mathrm{O}$ content) of these lignin residues are shown in Figure 4. Accordingly, the oxygen content of the residues obtained using Ni/ASA (12\%), $\mathrm{CuMgAlO}_{x}$ and $\mathrm{Ni} / \mathrm{ASA}(11 \%)$, and $\mathrm{CuMgAlO}$, and $\mathrm{Ni}_{2} \mathrm{P} /$ $\mathrm{SiO}_{2}(11 \%)$ were much lower than that of the parent lignin (32\%) (Figure 4 and Table 3). The oxygen content of the $\mathrm{CuMgAlO}_{x}(14 \%)$ and $\mathrm{CuMgAlO}$ and $\mathrm{Ni} / \mathrm{SiO}_{2}(15 \%)$ were

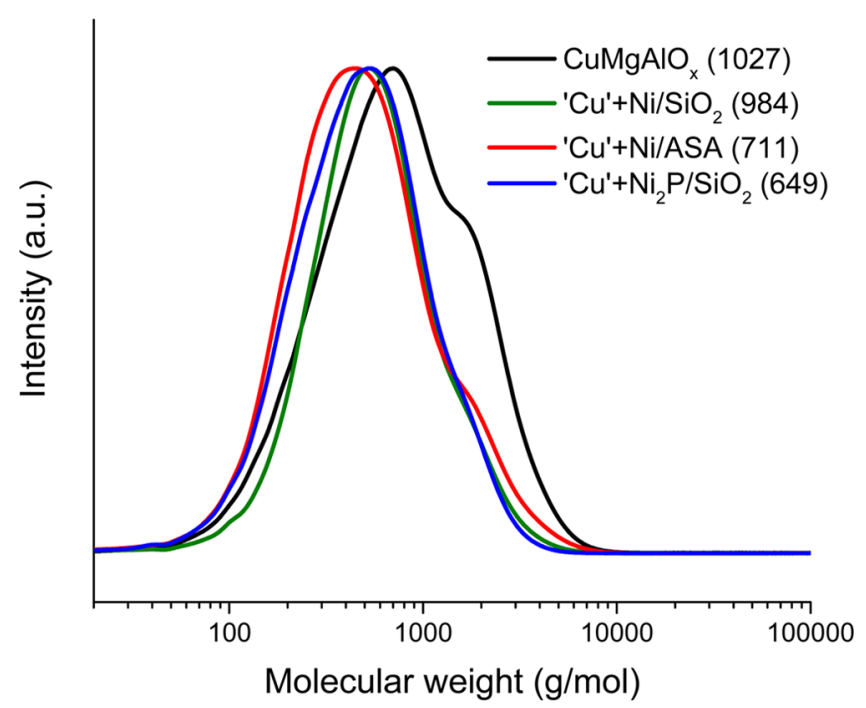

Figure 3. GPC-derived molecular-weight distributions of the THFsoluble fraction of the lignin residue over $\mathrm{CuMgAlO}_{x}$ ("Cu") and combined $\mathrm{Cu}$ and $\mathrm{Ni} / \mathrm{SiO}_{2}, \mathrm{Cu}$ and $\mathrm{Ni} / \mathrm{ASA}$, and $\mathrm{Cu}$ and $\mathrm{Ni}_{2} \mathrm{P} / \mathrm{SiO}_{2}$ catalysts (the number between brackets is the weight-averaged molecular weight).

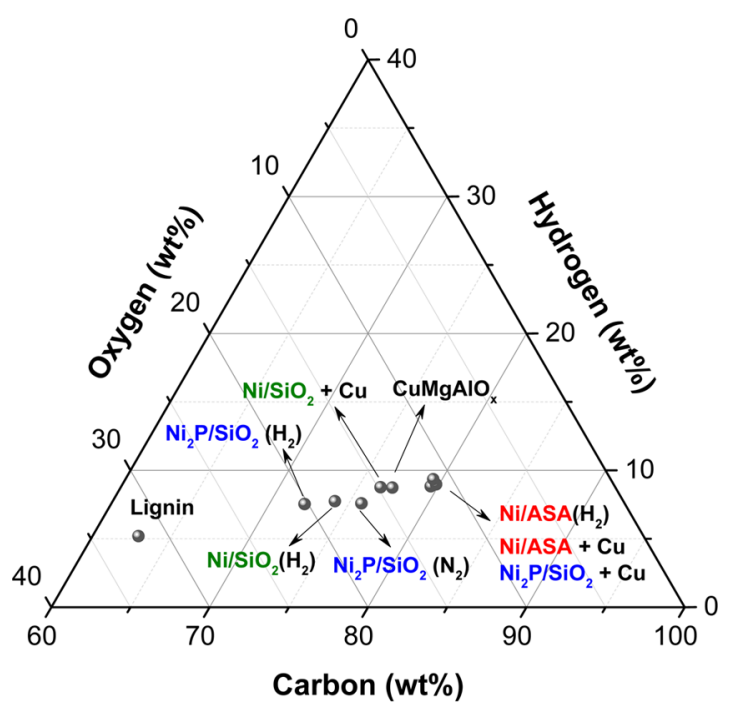

Figure 4. Elemental analysis of the THF-soluble fraction of the $\mathrm{P} 1000$ lignin and its residue over $\mathrm{Ni} / \mathrm{SiO}_{2}, \mathrm{Ni} / \mathrm{ASA}, \mathrm{Ni}_{2} \mathrm{P} / \mathrm{SiO}_{2}\left(\mathrm{~N}_{2}\right), \mathrm{Ni}_{2} \mathrm{P} /$ $\mathrm{SiO}_{2}\left(\mathrm{H}_{2}\right), \mathrm{CuMgAlO}_{x}$ ("Cu"), and combined $\mathrm{Cu}$ and $\mathrm{Ni} / \mathrm{SiO}_{2}, \mathrm{Cu}$ and $\mathrm{Ni} / \mathrm{ASA}$, and $\mathrm{Cu}$ and $\mathrm{Ni}_{2} \mathrm{P} / \mathrm{SiO}_{2}$ catalysts. 

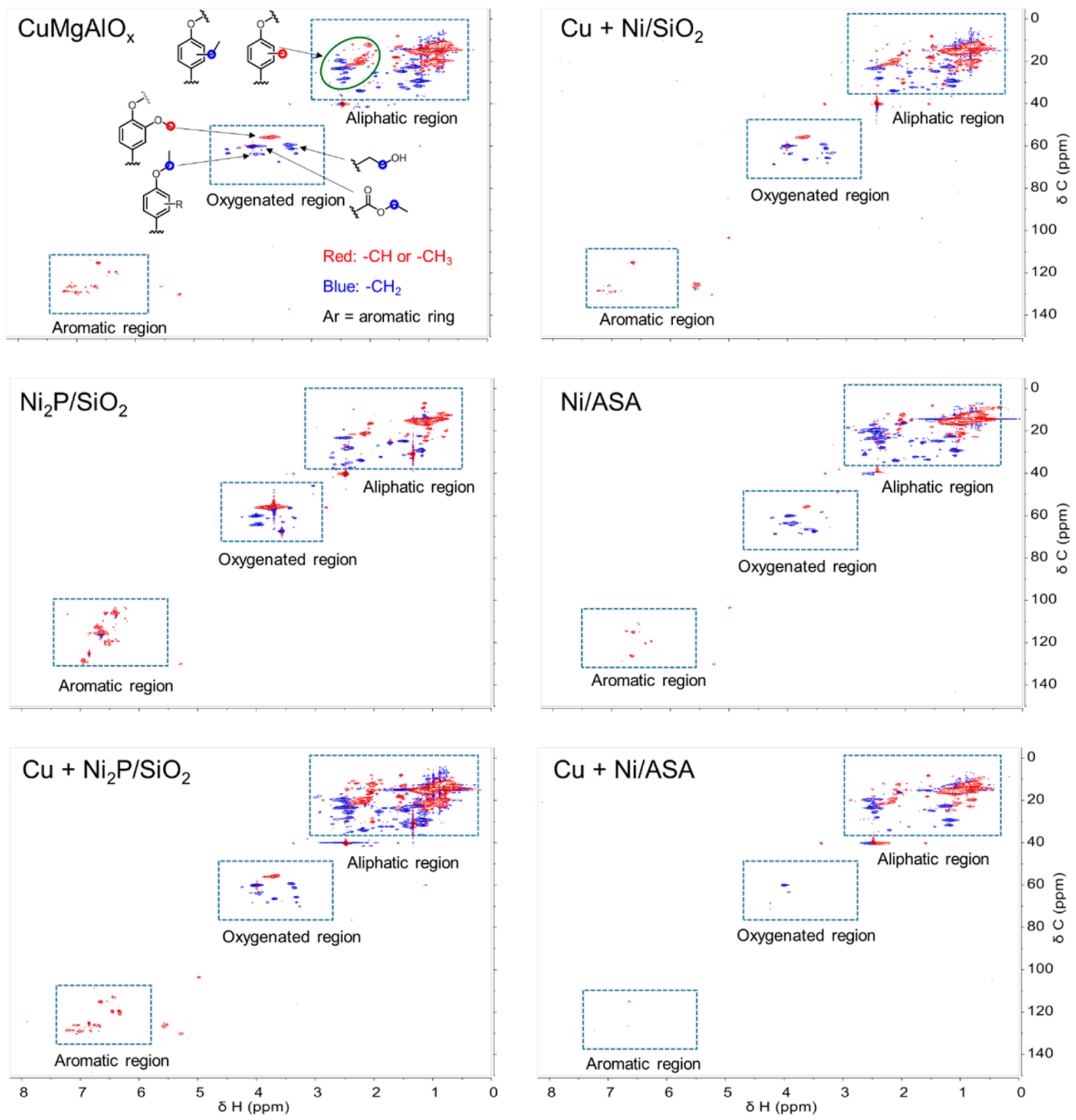

Figure 5. ${ }^{1} \mathrm{H}-{ }^{13} \mathrm{C}$ HSQC NMR spectra of the THF-soluble lignin residue obtained from the lignin reaction at $340{ }^{\circ} \mathrm{C}$ for $4 \mathrm{~h}$ over the $\mathrm{CuMgAlO}{ }_{x}$ (“Cu"), $\mathrm{Ni}_{2} \mathrm{P} / \mathrm{SiO}_{2}, \mathrm{Ni} / \mathrm{ASA}$, and combined $\mathrm{Cu}+\mathrm{Ni} / \mathrm{SiO}_{2}, \mathrm{Cu}+\mathrm{Ni}_{2} \mathrm{P} / \mathrm{SiO}_{2}$, and $\mathrm{Cu}+\mathrm{Ni} / \mathrm{ASA}$ catalysts in ethanol solvent.

slightly higher, suggesting that the combined catalytic systems with $\mathrm{Ni}_{2} \mathrm{P}$ and $\mathrm{Ni} / \mathrm{ASA}$ were effective in reducing the oxygen content already of the light (THF-soluble) lignin residue (Table 3).

Two-dimensional heteronuclear single quantum coherence (HSQC) NMR is frequently employed for the characterization of the starting lignin and solid lignin residues. ${ }^{42}$ We proved in this way that significant alkylation reactions occur on the aromatic rings and phenolic groups of the solid fraction during deconstruction with $\mathrm{CuMgAlO}_{x}$ as the catalyst. ${ }^{14}$ These Calkylated and oxygenated (O-alkylated) groups are marked in the HSQC NMR spectra shown in Figure 5. Comparing the different spectra, it is seen that the amount of C-alkylated groups in the light residue is higher for the $\mathrm{CuMgAlO}_{x}$ and combined $\mathrm{CuMgAlO}_{x}$ and $\mathrm{Ni}_{2} \mathrm{P} / \mathrm{SiO}_{2}$ catalyzed experiments than for $\mathrm{Ni}_{2} \mathrm{P} / \mathrm{SiO}_{2}$ catalyzed one, while the intensity of aromatic $\mathrm{H}$ groups decreases (Figure 5). Such changes were not observed for the residue obtained using the combination of $\mathrm{CuMgAlO}_{x}$ and $\mathrm{Ni} / \mathrm{SiO}_{2}$ and $\mathrm{CuMgAlO}_{x}$ and $\mathrm{Ni} / \mathrm{ASA}$ catalysts (Figure 5). Thus, we infer that alkylation is enhanced slightly by $\mathrm{Ni}_{2} \mathrm{P}$, whereas reduced $\mathrm{Ni}$ catalysts are not active in alkylation.

Heavy (THF-insoluble) lignin residue and char represent the repolymerized lignin fragments. ${ }^{12}$ They originate from condensation reactions between lignin fragments and they are typically adsorbed to the solid catalyst. ${ }^{14}$ The basic sites of $\mathrm{CuMgAlO}_{x}$ catalyst help to reduce char formation (Table 3). ${ }^{14}$ Very few heavy residue and char were formed on the single $\mathrm{Ni}$ based catalysts, except when the $\mathrm{Ni}_{2} \mathrm{P} / \mathrm{SiO}_{2}$ catalyst was used without added hydrogen (entry 2 in Table 3 ). This result shows 
Table 4. Lignin Monomer Yield Distributions, Aromatic HYD and HDO Degrees, and Ethanol-Product Yields Using Different Ratios of the CuMgAlO ${ }_{x}$ and $\mathrm{Ni}_{2} \mathrm{P} / \mathrm{SiO}_{2}$ Catalysts at $340{ }^{\circ} \mathrm{C}$

\begin{tabular}{|c|c|c|c|c|c|c|c|c|c|}
\hline \multirow[b]{2}{*}{ entry } & \multirow[b]{2}{*}{$\mathrm{CuMgAlO}_{x}: \mathrm{Ni}_{2} \mathrm{P}$ mass ratio } & \multicolumn{5}{|c|}{ lignin monomer yield (wt \%) } & \multirow[b]{2}{*}{ aromatic HYD degree (wt \%) } & \multirow[b]{2}{*}{ HDO degree (wt \%) } & \multirow[b]{2}{*}{ ethanol product yield (wt \%) } \\
\hline & & $\mathrm{HC}^{-\mathrm{O}}$ & $\mathrm{Ar}^{-\mathrm{O}}$ & $\mathrm{HC}^{+\mathrm{O}}$ & $\mathrm{Ar}^{+\mathrm{O}}$ & sum & & & \\
\hline 1 & $0: 1$ & 0.6 & 0.2 & 0.2 & 6.9 & 8 & 9 & 10 & 3 \\
\hline 2 & $0.25: 0.75$ & 19.7 & 5.1 & 6.2 & 12.1 & 43 & 60 & 57 & 16 \\
\hline 3 & $0.5: 0.5$ & 20.5 & 23.1 & 2.1 & 6.8 & 53 & 43 & 83 & 14 \\
\hline 4 & $0.75: 0.25$ & 18.5 & 5.9 & 6.7 & 18.6 & 50 & 51 & 49 & 13 \\
\hline 5 & $1: 0$ & 2.8 & 9.9 & 5.1 & 9.3 & 27 & 29 & 47 & 11 \\
\hline 6 & $0.5: 0.5^{a}$ & 45.0 & 17.1 & 7.6 & 10.3 & 80 & 66 & 78 & 21 \\
\hline
\end{tabular}

${ }^{a} 8 \mathrm{~h}$ reaction time.

that a hydrogenation functionality can prevent repolymerization reactions during lignin upgrading and it most likely relates to the saturation of reactive carbon-carbon double bonds. Comparatively, more heavy lignin residue and char were obtained when $\mathrm{CuMgAlO}_{x}$ was combined with $\mathrm{Ni} / \mathrm{ASA}$ (entry 6 in Table 3). This most likely correlates with the lower contribution of Guerbet-type reactions (entry 6 in Table S2), which are known to suppress repolymerization and char formation. ${ }^{14}$ Altogether, the sum of heavy lignin residue and char were similar in the $\mathrm{CuMgAlO}_{x}$ and combined $\mathrm{CuMgAlO}{ }_{x}$ and $\mathrm{Ni}\left({ }_{2} \mathrm{P}\right) / \mathrm{SiO}_{2}$ catalyst systems (entries 1,4 , and 8 in Table 3 ), which means that the degree of repolymerization is also similar in these reactions.

We also varied the ratio of the $\mathrm{CuMgAlO}$ and $\mathrm{Ni}_{2} \mathrm{P} / \mathrm{SiO}_{2}$ catalysts toward optimum lignin monomer yield. To this end, we kept the total catalyst mass at $1 \mathrm{~g}$ and varied the amounts in the following ratios 0:1, 0.25:0.75, 0.5:0.5, 0.75:0.25, and 1:0. Lignin monomers yield, aromatic HYD and HDO degrees, and ethanol product yields are presented in Table 4. In all three cases where two catalysts were combined, there was a clear synergy in terms of the lignin monomer yield. Overall the highest lignin monomer yield was obtained when an equivalent ratio of the two catalysts was used. At the same time, the HDO degree was much higher for the optimum catalysts ratio, presumably indicating that the synergy is at least in part related to removal of oxygen species. This should be related to a reduction of phenolic groups that can be involved in repolymerization reactions. It can also be seen that there is only a slight effect on the ethanol-product yield when the $\mathrm{CuMgAlO}_{x}$ content is varied. Finally, we employed the optimum catalyst combination in an experiment where the reaction time was extended to $8 \mathrm{~h}$ at $340{ }^{\circ} \mathrm{C}$. Compared to the $4 \mathrm{~h}$ experiment, the lignin monomer yield was increased to 80 wt $\%$ at nearly similar HDO degree of 78 wt \%. At the same time, however, the aromatics hydrogenation degree was higher at $66 \mathrm{wt} \%$ and also slightly more ethanol-derived products were formed.

\section{CONCLUSIONS}

The use of Ni-based $\mathrm{HDO}$ cocatalysts for the $\mathrm{CuMgAlO}_{x^{-}}$ catalyzed depolymerization of soda lignin in supercritical ethanol was investigated. $\mathrm{Ni} / \mathrm{ASA}$ and $\mathrm{Ni} / \mathrm{SiO}_{2}$ catalysts were prepared by incipient wetness impregnation. The $\mathrm{Ni}_{2} \mathrm{P} / \mathrm{SiO}_{2}$ catalyst was obtained by impregnation of $\mathrm{NiO} / \mathrm{SiO}_{2}$ with diammonium phosphate and reduction at $620{ }^{\circ} \mathrm{C}$. While Ni/ $\mathrm{SiO}_{2}$ and $\mathrm{Ni}_{2} \mathrm{P} / \mathrm{SiO}_{2}$ displayed poor performance in the deconstructing lignin without $\mathrm{CuMgAlO}_{x}$, metallic Ni dispersed on the acidic ASA support gave similar yields as the mixed oxide catalyst. The high acidity of the support resulted in high solvent conversion (diethyl-ether formation). The $\mathrm{Ni} / \mathrm{SiO}_{2}$ and $\mathrm{Ni}_{2} \mathrm{P} / \mathrm{SiO}_{2}$ were found to operate synergetically with $\mathrm{CuMgAlO}_{x}$ in soda lignin depolymerization. The lignin monomer yield was strongly increased and at the same time the degree of oxygen removal was much higher. As hydrogen is in situ formed due to the action of $\mathrm{CuMgAlO}_{x}$, these experiments did not require the addition of hydrogen. The best overall performance is achieved by combining $\mathrm{CuMgAlO}_{x}$ with $\mathrm{Ni}_{2} \mathrm{P} / \mathrm{SiO}_{2}$, resulting in 53 wt \% lignin monomers yield at a $\mathrm{HDO}$ degree of $83 \mathrm{wt} \% \mathrm{HDO}$. One aspect of the observed synergy is that in situ hydrogen generation by the $\mathrm{CuMgAlO}_{x}$ catalyst will not only activate the supported $\mathrm{Ni}$ and $\mathrm{Ni}$ phosphide catalysts but also retain them in a highly active state. The other important aspect is that the Ni-based phases are involved in hydrogenation of reactive intermediates released from lignin by the action of the $\mathrm{CuMgAlO}_{x}$ catalyst. Such reactive intermediates contain aldehyde and olefinic groups, which are known to be involved in condensation reactions that will decrease the lignin monomer yield.

\section{ASSOCIATED CONTENT}

\section{Supporting Information}

The Supporting Information is available free of charge on the ACS Publications website at DOI: 10.1021/acssuschemeng.7b00239.

Expanded descriptions of experimental procedures, gas phase products, ethanol conversion product yield and distribution, and characterization of the spent and regenerated catalyst (PDF)

\section{AUTHOR INFORMATION}

\section{Corresponding Author}

*E-mail: e.j.m.hensen@tue.nl.

ORCID 우

Emiel J. M. Hensen: 0000-0002-9754-2417

Author Contributions

${ }^{\dagger}$ T.I.K. and X.H. contributed equally to this work.

Notes

The authors declare no competing financial interest.

\section{ACKNOWLEDGMENTS}

This research has been performed within the framework of the CatchBio program under project number 053.70.337.

\section{REFERENCES}

(1) Li, C. Z.; Zhao, X. C.; Wang, A. Q.; Huber, G. W.; Zhang, T. Catalytic Transformation of Lignin for the Production of Chemicals and Fuels. Chem. Rev. 2015, 115, 11559-11624. 
(2) Huber, G. W.; Iborra, S.; Corma, A. Synthesis of transportation fuels from biomass: Chemistry, catalysts, and engineering. Chem. Rev. 2006, 106, 4044-4098.

(3) Ragauskas, A. J.; Beckham, G. T.; Biddy, M. J.; Chandra, R.; Chen, F.; Davis, M. F.; Davison, B. H.; Dixon, R. A.; Gilna, P.; Keller, M.; Langan, P.; Naskar, A. K.; Saddler, J. N.; Tschaplinski, T. J.; Tuskan, G. A.; Wyman, C. E. Lignin valorization: improving lignin processing in the biorefinery. Science 2014, 344, 1246843.

(4) Zakzeski, J.; Bruijnincx, P. C. A.; Jongerius, A. L.; Weckhuysen, B. M. The Catalytic Valorization of Lignin for the Production of Renewable Chemicals. Chem. Rev. 2010, 110, 3552-3599.

(5) Strassberger, Z.; Tanase, S.; Rothenberg, G. The pros and cons of lignin valorisation in an integrated biorefinery. RSC $A d v$. 2014, 4, 25310-25318.

(6) Pandey, M. P.; Kim, C. S. Lignin Depolymerization and Conversion: A Review of Thermochemical Methods. Chem. Eng. Technol. 2011, 34, 29-41.

(7) Roberts, V. M.; Stein, V.; Reiner, T.; Lemonidou, A.; Li, X. B.; Lercher, J. A. Towards Quantitative Catalytic Lignin Depolymerization. Chem. - Eur. J. 2011, 17, 5939-5948.

(8) Barta, K.; Matson, T. D.; Fettig, M. L.; Scott, S. L.; Iretskii, A. V.; Ford, P. C. Catalytic disassembly of an organosolv lignin via hydrogen transfer from supercritical methanol. Green Chem. 2010, 12, 16401647.

(9) Song, Q.; Wang, F.; Cai, J. Y.; Wang, Y. H.; Zhang, J. J.; Yu, W. Q.; Xu, J. Lignin depolymerization (LDP) in alcohol over nickel-based catalysts via a fragmentation-hydrogenolysis process. Energy Environ. Sci. 2013, 6, 994-1007.

(10) Ma, R.; Hao, W. Y.; Ma, X. L.; Tian, Y.; Li, Y. D. Catalytic Ethanolysis of Kraft Lignin into High-Value Small-Molecular Chemicals over a Nanostructured alpha-Molybdenum Carbide Catalyst. Angew. Chem., Int. Ed. 2014, 53, 7310-7315.

(11) Wang, X. Y.; Rinaldi, R. Solvent Effects on the Hydrogenolysis of Diphenyl Ether with Raney Nickel and their Implications for the Conversion of Lignin. ChemSusChem 2012, 5, 1455-1466.

(12) Huang, X.; Korányi, T. I.; Boot, M. D.; Hensen, E. J. M. Catalytic Depolymerization of Lignin in Supercritical Ethanol. ChemSusChem 2014, 7, 2276-2288.

(13) Huang, X.; Korányi, T. I.; Boot, M. D.; Hensen, E. J. M. Ethanol as capping agent and formaldehyde scavenger for efficient depolymerization of lignin to aromatics. Green Chem. 2015, 17, 4941-4950.

(14) Huang, X.; Atay, C.; Korányi, T. I.; Boot, M. D.; Hensen, E. J. M. Role of $\mathrm{Cu}-\mathrm{Mg}-\mathrm{Al}$ Mixed Oxide Catalysts in Lignin Depolymerization in Supercritical Ethanol. ACS Catal. 2015, 5, 7359-7370.

(15) Shafaghat, H.; Rezaei, P. S.; Ashri Wan Daud, W. M. Effective parameters on selective catalytic hydrodeoxygenation of phenolic compounds of pyrolysis bio-oil to high-value hydrocarbons. RSC Adv. 2015, 5, 103999-104042.

(16) Topsøe, H.; Clausen, B. S.; Massoth, F. E. Hydrotreating Catalysis. In Hydrotreating Catalysis, Science and Technology; SpringerVerlag: Berlin, Germany, 1996.

(17) Lauritsen, J. V.; Kibsgaard, J.; Olesen, G. H.; Moses, P. G.; Hinnemann, B.; Helveg, S.; Nørskov, J. K.; Clausen, B. S.; Topsøe, H.; Lægsgaard, E.; Besenbacher, F. Location and coordination of promoter atoms in Co- and Ni-promoted MoS2-based hydrotreating catalysts. J. Catal. 2007, 249, 220-233.

(18) Boullosa-Eiras, S.; Lødeng, R.; Bergem, H.; Stöcker, M.; Hannevold, L.; Blekkan, E. A. Potential for metal-carbide, -nitride, and -phosphide as future hydrotreating (HT) catalysts for processing of bio-oils. Catalysis 2014, 26, 29-71.

(19) Prins, R.; Bussell, M. E. Metal Phosphides: Preparation, Characterization and Catalytic Reactivity. Catal. Lett. 2012, 142, $1413-1436$

(20) Oyama, S. T.; Gott, T.; Zhao, H.; Lee, Y. K. Transition metal phosphide hydroprocessing catalysts: A review. Catal. Today 2009, 143, 94-107.
(21) Brock, S. L.; Senevirathne, K. Recent developments in synthetic approaches to transition metal phosphide nanoparticles for magnetic and catalytic applications. J. Solid State Chem. 2008, 181, 1552-1559.

(22) Alexander, A. M.; Hargreaves, J. S. J. Alternative catalytic materials: carbides, nitrides, phosphides and amorphous boron alloys. Chem. Soc. Rev. 2010, 39, 4388-4401.

(23) Robinson, W. R. A. M.; van Gestel, J. N. M.; Korányi, T. I.; Eijsbouts, S.; van der Kraan, A. M.; van Veen, J. A. R.; de Beer, V. H. J. Phosphorus Promotion of $\mathrm{Ni}(\mathrm{Co})$-Containing Mo-Free Catalysts in Quinoline Hydrodenitrogenation. J. Catal. 1996, 161, 539-550.

(24) Korányi, T. I. Phosphorus promotion of $\mathrm{Ni}(\mathrm{Co})$-containing Mo-free catalysts in thiophene hydrodesulfurization. Appl. Catal., A 2003, 239, 253-267.

(25) Zhao, H. Y.; Li, D.; Bui, P.; Oyama, S. T. Hydrodeoxygenation of guaiacol as model compound for pyrolysis oil on transition metal phosphide hydroprocessing catalysts. Appl. Catal., A 2011, 391, 305310.

(26) Wu, S. K.; Lai, P. C.; Lin, Y. C.; Wan, H. P.; Lee, H. T.; Chang, Y. H. Atmospheric Hydrodeoxygenation of Guaiacol over Alumina-, Zirconia-, and Silica-Supported Nickel Phosphide Catalysts. ACS Sustainable Chem. Eng. 2013, 1, 349-358.

(27) Wu, S. K.; Lai, P. C.; Lin, Y. C. Atmospheric Hydrodeoxygenation of Guaiacol over Nickel Phosphide Catalysts: Effect of Phosphorus Composition. Catal. Lett. 2014, 144, 878-889.

(28) Cecilia, J. A.; Infantes-Molina, A.; Rodríguez-Castellón, E.; Jiménez-López, A.; Oyama, S. T. Oxygen-removal of dibenzofuran as a model compound in biomass derived bio-oil on nickel phosphide catalysts: Role of phosphorus. Appl. Catal., B 2013, 136-137, 140149.

(29) Iino, A.; Cho, A.; Takagaki, A.; Kikuchi, R.; Ted Oyama, S. Kinetic studies of hydrodeoxygenation of 2-methyltetrahydrofuran on a $\mathrm{Ni}_{2} \mathrm{P} / \mathrm{SiO}_{2}$ catalyst at medium pressure. J. Catal. 2014, 311, 17-27.

(30) Koike, N.; Hosokai, S.; Takagaki, A.; Nishimura, S.; Kikuchi, R.; Ebitani, K.; Suzuki, Y.; Oyama, S. T. Upgrading of pyrolysis bio-oil using nickel phosphide catalysts. J. Catal. 2016, 333, 115-126.

(31) Kasakov, S.; Shi, H.; Camaioni, D. M.; Zhao, C.; Barath, E.; Jentys, A.; Lercher, J. A. Reductive deconstruction of organosolv lignin catalyzed by zeolite supported nickel nanoparticles. Green Chem. 2015, 17, 5079-5090.

(32) Kong, J. C.; He, M. Y.; Lercher, J. A.; Zhao, C. Direct production of naphthenes and paraffins from lignin. Chem. Commun. 2015, 51, 17580-17583.

(33) Wang, X.; Rinaldi, R. Bifunctional Ni catalysts for the one-pot conversion of Organosolv lignin into cycloalkanes. Catal. Today 2016, $269,48-55$.

(34) Maxwell, I. E.; Naber, J. E.; de Jong, K. P. The pivotal role of catalysis in energy related environmental technology. Appl. Catal., A 1994, 113, 153-173.

(35) De, S.; Zhang, J.; Luque, R.; Yan, N. Ni-based bimetallic heterogeneous catalysts for energy and environmental applications. Energy Environ. Sci. 2016, 9, 3314-3347.

(36) Grob, R. L.; Barry, E. F. Modern practice of gas chromatography; Wiley: Hoboken, 2004; pp 302-303.

(37) Barta, K.; Ford, P. C. Catalytic Conversion of Nonfood Woody Biomass Solids to Organic Liquids. Acc. Chem. Res. 2014, 47, 15031512.

(38) O'Lenick, A. J. Guerbet chemistry. J. Surfactants Deterg. 2001, 4, $311-315$.

(39) Kozlowski, J. T.; Davis, R. J. Heterogeneous Catalysts for the Guerbet Coupling of Alcohols. ACS Catal. 2013, 3, 1588-1600.

(40) Di Cosimo, J. I.; Diez, V. K.; Xu, M.; Iglesia, E.; Apesteguia, C. $\mathrm{R}$. Structure and surface and catalytic properties of $\mathrm{Mg}$-Al basic oxides. J. Catal. 1998, 178, 499-510.

(41) Kraus, L. S.; Pines, H.; Butt, J. B. Properties of $\mathrm{Ni} / \mathrm{SiO}_{2}$ catalysts: Relationship to ether formation from alcohols. J. Catal. 1991, 128, 337-351.

(42) Yuan, T. Q.; Sun, S. N.; Xu, F.; Sun, R. C. Characterization of Lignin Structures and Lignin-Carbohydrate Complex (LCC) Linkages 
by Quantitative C-13 and 2D HSQC NMR Spectroscopy. J. Agric.

Food Chem. 2011, 59, 10604-10614. 